\title{
Comparison of milk production, intake, and total-tract nutrient digestion in lactating dairy cattle fed diets containing either wheat middlings and urea, commercial fermentation by-product, or rumen-protected soybean meal
}

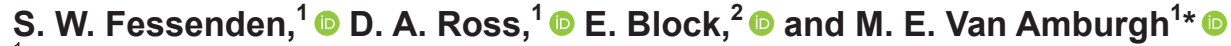 \\ ${ }^{1}$ Department of Animal Science, Cornell University, Ithaca, NY 14850 \\ ${ }^{2}$ Arm and Hammer Animal Nutrition, Princeton, NJ 08543
}

\begin{abstract}
The objective of this study was to evaluate the effects of a commercially available fermentation by-product in a diet containing adequate rumen-degradable protein (RDP) on milk performance, intake, and total-tract nutrient digestion in lactating dairy cattle. Primiparous $(\mathrm{n}=48)$ and multiparous $(\mathrm{n}=144)$ lactating dairy cattle were stratified by milk production and randomly allocated into 12 pens containing 4 primiparous and 12 multiparous animals each. Cattle averaged $118 \mathrm{~d}$ in milk and $712 \mathrm{~kg}$ of body weight at trial start. Treatment diets, on a dry matter (DM) basis, consisted of $42 \%$ corn silage, $13 \%$ alfalfa hay and silage, $20 \%$ grain corn, and $25 \%$ protein premix containing either soybean meal, wheat middlings, and urea $(\mathrm{SBM}+\mathrm{U})$, soybean meal and fermentation by-product $(\mathrm{SBM}+\mathrm{F})$, or soybean meal and rumen-protected soybean meal (RP-SBM). All 3 diets provided a similar level (DM basis) of neutral detergent fiber analyzed using $\alpha$-amylase and sodium sulfite and corrected for ash content (31\%), crude protein (CP, 14.9\%), starch (26\%), and metabolizable energy $(2.7 \mathrm{Mcal} / \mathrm{kg})$, and differed in sources of RDP. The trial consisted of a 2-wk adaptation and covariate period during which all cows were fed the RP-SBM diet and covariate measurements were taken. Pens were then randomly allocated to treatments, and weekly measurements of milk production, intake, body weight, and condition score were taken for $10 \mathrm{wk}$. All data were analyzed using the Proc Mixed procedure in SAS (SAS Institute Inc., Cary, NC). Increased DM intake was observed for cows fed SBM+F compared with cows fed SBM+U and RP-SBM (28.3 vs. 26.9 and 26.7 $\mathrm{kg} / \mathrm{d}$, respectively). Cows fed $\mathrm{SBM}+\mathrm{F}$ produced more energy-corrected milk $(45.3 \mathrm{~kg} / \mathrm{d})$ compared with cows fed SBM+U and RP-SBM (43.6 and $43.7 \mathrm{~kg} / \mathrm{d}$, respectively). Milk protein yield was also increased in cows
\end{abstract}

Received October 14, 2019.

Accepted January 29, 2020.

*Corresponding author: mev1@cornell.edu fed SBM+F. No differences were observed with body weight or condition score gain throughout the trial. Apparent total-tract digestibility of fiber was decreased in cows fed $\mathrm{SBM}+\mathrm{F}$, likely as a result of increased intake. Responses are consistent with previous research in our laboratory that demonstrated a decrease in ruminal CP degradation, leading to an increase in metabolizable protein supply in the small intestine. The fermentation by-product might be useful in diets containing adequate amounts of RDP from soybean meal or alfalfa. The results from this experiment demonstrate beneficial milk performance responses to fermentation by-product when fed with a source of RDP.

Key words: milk performance, nitrogen, rumendegradable protein, Fermenten, dairy cow

\section{INTRODUCTION}

The ability of rumen microbial populations to utilize substrate that would otherwise be unavailable to mammalian enzyme systems allows lactating dairy cattle to produce milk using relatively poor-quality feed ingredients compared with non-ruminants. Microbial populations in the rumen can convert non-protein $\mathrm{N}$ compounds into high-quality MP when provided sufficient degradable carbohydrate (Firkins, 1996; Hackmann and Firkins, 2015). However, fermentation and conversion of rumen-degraded protein to ammonia can cause excessive $\mathrm{N}$ losses to the environment (Castillo et al., 2000). The most effective way to reduce $\mathrm{N}$ losses is through reduced CP feeding while maintaining MP balance and high levels of milk protein output (Huhtanen and Hristov, 2009; Broderick, 2017).

By-products from human production can be fed to ruminant animals and provide an opportunity to more efficiently utilize feedstuffs that might otherwise be discarded (VandeHaar and St-Pierre, 2006; Karlsson et al., 2018). Fermenten (Church and Dwight Inc., Princeton, NJ) is a commercially available fermentation byproduct derived from glutamic acid production, which contains large amounts of rumen-available nitrogen 
compounds in the form of soluble AA, small peptides, and ammonia nitrogen. Lean et al. (2005) indicated that fermentation by-products can increase the flow of microbial protein from continuous-flow fermenters with rumen microbes, likely through stimulation of microbial protein synthesis (Cotta and Russell, 1982). However, production responses in vivo have been inconsistent (Broderick et al., 2000; Penner et al., 2009). Fessenden et al. (2019a,b) reported that fermentation by-product inclusion did not stimulate microbial protein synthesis but did increase daily non-microbial, non-ammonia nitrogen flow from the rumen greater than the amount of RUP supplied by diet differences alone, resulting in a $15 \%$ reduction in observed dietary protein degradation in the rumen. Fessenden et al. (2019a) discussed possible mechanisms for this associative effect of fermentation by-product on other dietary protein sources; however, the specific mode of action is still unclear. Nonetheless, the observed reduction in dietary protein degradation, as reported in Fessenden et al. (2019a), could provide some benefit when included in diets containing higher levels of rumen-degradable AA.

Predicting such responses when balancing rations in the field can be difficult without a mechanistic understanding of microbial fermentation, animal requirements, and subsequent utilization of supplied nutrients. Integrated mathematical models such as the Cornell Net Carbohydrate and Protein System (CNCPS; Higgs et al., 2015; Van Amburgh et al., 2015) have been successfully used in production systems across the world to improve economic and environmental efficiency of milk production (Tylutki et al., 2008; Russomanno et al., 2013). Successful model development and implementation requires proper characterization of farm, animal, and feed characteristics.

The hypothesis of this study was that (1) inclusion of fermentation by-product in a diet with adequate RDP from soybean meal would increase productive performance in dairy cows compared with cows fed a diet containing soybean meal, wheat middlings, and urea, and (2) the cows fed the fermentation by-product diet would have similar performance to cows fed a diet containing soybean meal and rumen-protected soybean meal. A secondary objective was to provide well-characterized feed and cattle information to aid in future model development and evaluation.

\section{MATERIALS AND METHODS}

The experiment was conducted from February to April 2016 at the Cornell University Ruminant Center in Harford, NY. All animals involved in this experiment were cared for according to the guidelines of the Cornell University Animal Care and Use Committee. The com- mittee reviewed and approved the experiment and all procedures carried out in the study.

\section{Animals and Experimental Design}

Lactating dairy cattle $(\mathrm{n}=192)$ were enrolled in a 12-wk longitudinal trial with 2 wk of acclimation and covariate sampling followed by $10 \mathrm{wk}$ of experimental data collection. Cattle averaged (mean $\pm \mathrm{SD}$ ) $118 \pm 37$ DIM and $712 \pm 88 \mathrm{~kg}$ of BW at trial start. Primiparous $(\mathrm{n}=48)$ and multiparous $(\mathrm{n}=144)$ cattle were stratified by pre-trial milk production and randomly allocated into 12 pens containing 4 primiparous and 12 multiparous cows each. All pens were fed the same diet during the acclimation and covariate periods. After 1 wk of acclimation to pens, covariate measurements were taken in the same manner described below for the experimental period. Pens were then randomly allocated to 1 of 3 dietary treatments and remained on those treatments for the remainder of the study. All cows were administered bovine somatotropin (500 mg of Posilac; Elanco Animal Health, Greenfield, IN) on the same 14-d interval, according to manufacturer's instructions. Cattle were housed in a modern 4-row freestall barn in pens with at least 16 stalls and 16 headlocks per pen, and had free access to feed, water, and bedding at all times. Cows were milked $3 \times$ daily at 0800 h, 1600 h, and 2400 h in a double-16 parlor. Feed refusals were collected and measured daily at $0600 \mathrm{~h}$, and cattle were fed once daily at $0800 \mathrm{~h}$ to target feed refusals of $5 \%$ of daily intake.

\section{Diets and Sample Collection}

Treatment diets consisted of (DM basis) $42 \%$ corn silage, $5 \%$ alfalfa silage, $8 \%$ alfalfa hay, $12.4 \%$ steamflaked corn, $7.6 \%$ corn meal, and $25 \%$ protein premix containing either soybean meal, wheat middlings, and urea, $(\mathbf{S B M}+\mathbf{U})$, soybean meal and Fermenten $(\mathbf{S B M}+\mathbf{F})$, or soybean meal and rumen-protected soybean meal (RP-SBM). The only other difference between diets was the partial substitution of calcium carbonate for calcium sulfate in diets $\mathrm{SBM}+\mathrm{U}$ and RP-SBM. This was done to maintain similar $\mathrm{Ca}$ and $\mathrm{S}$ levels in all diets, as the fermentation by-product contains relatively high levels of S. All diets were balanced (assuming $45 \mathrm{~kg} / \mathrm{d}$ of ECM) to be sufficient in $\mathrm{ME}$ and rumen $\mathrm{NH}_{3}-\mathrm{N}$ balance using CNCPS version 6.55 (Higgs et al., 2015; Van Amburgh et al., 2015). The protein premix for each diet was mixed at a commercial feed mill (CNY Feeds Inc., Jordan, NY) and delivered every $3 \mathrm{wk}$ for the duration of the trial. All cows were fed the RP-SBM diet during the acclimation and covariate period, as this diet was considered to be 
a positive control and was most similar to the diet that animals were fed before the experiment began. Weekly samples of forages were collected, and a portion was sent to a commercial laboratory (Cumberland Valley Analytical Services, Maugansville, MD) for chemical and nutrient analysis (Table 1), and another portion was analyzed for DM by drying at $60^{\circ} \mathrm{C}$ for $96 \mathrm{~h}$, followed by grinding through a 1-mm screen (Wiley Mill no. 4, Arthur H. Thomas, Philadelphia, PA). Ingredient inclusion was adjusted for DM content to maintain intended formulation (Table 2). Samples of corn meal, steam-flaked corn, and refusals were sampled weekly, dried and ground as described above, and composited by ingredient into 3 separate samples representing 3 or 4 consecutive weeks and analyzed for major nutrients (data not shown). Individual ingredients in the premixes were obtained from the mill 3 times during the experiment and analyzed for major nutrients to ensure intended formulation. Total mixed ration was prepared fresh each day. Samples of TMR were collected twice weekly, analyzed for DM, ground and composited as described above, and analyzed for nutrient composition (Table 3). Daily DMI per pen was calculated from daily feed amounts offered and refused, corrected for DM determined from individual ingredient values, and verified by DM determinations of TMR, feeds, and refusals. Deviation from intended formulation was tracked with a commercially available feed management program (FeedWatch, Valley Agricultural Software, Tulare, CA).

Body weights on every animal were measured weekly after the $1600 \mathrm{~h}$ milking, and BCS (1 to 5 scale) was recorded weekly as the average of 2 trained scorers. Milk yield was recorded at every milking by farm software systems (ALPRO; DeLaval Inc., Kansas City, MO). Weekly milk samples were taken at 3 consecutive milkings and analyzed for fat, true protein, lactose, SCC, total solids, and MUN (Dairy One, Ithaca, NY) using Fourier-transform infrared spectroscopy (Milkoscan 6000; Foss Electric, Hillerød, Denmark). Daily milk composition was calculated using a weighted average of the 3 milkings. Weekly ECM yield was calculated using the equations of Tyrrell and Reid (1965).

Fecal samples were collected from a randomly selected subset of cows (2 primiparous and 6 multiparous) in each pen during the covariate, and from the same cows on wk 5 and 10 of the experimental period. On the day following milk and feed sampling for each respective week, 3 fecal spot samples $(\sim 500 \mathrm{~g} / \mathrm{cow})$ were taken at 0600,1200 , and $2200 \mathrm{~h}$, composited by pen, and frozen at $-20^{\circ} \mathrm{C}$. Samples were later thawed and mixed, and a subsample was dried at $60^{\circ} \mathrm{C}$ for $96 \mathrm{~h}$ and ground to pass a 1-mm screen. Dried and ground fecal samples were analyzed for starch, NDF analyzed using $\alpha$-amylase and sodium sulfite and corrected for ash content (aNDFom; Mertens, 2002), and undegraded NDF (uNDFom) after $240 \mathrm{~h}$ of in vitro incubation with rumen fluid, according to Raffrenato et al. (2018). Apparent total-tract digestion of DM, starch, and aNDFom was calculated using uNDFom as a marker, as described by Huhtanen et al. (1994).

Blood samples were collected during the covariate period and wk 5 and 9 , from the same subset of cows as the fecal sampling. Blood $(8 \mathrm{~mL})$ was collected via the coccygeal vein $8 \mathrm{~h}$ after feeding, into tubes containing

Table 1. Chemical composition (mean $\pm \mathrm{SD})^{1}$ of selected feeds used in the experiment

\begin{tabular}{lrrrr}
\hline Item $^{2}$ & Corn silage & Alfalfa silage & Alfalfa hay & Fermentation by-product \\
\hline DM, \% & $32.3 \pm 2.4$ & $41.9 \pm 7.6$ & $86.3 \pm 1.6$ & $91.3 \pm 0.6$ \\
CP, \% of DM & $7.8 \pm 0.4$ & $17.1 \pm 1.6$ & $18.8 \pm 1.6$ & $52.6 \pm 1.6$ \\
NH 3 -N CPE, \% of CP & $11.3 \pm 0.7$ & $9.9 \pm 3.3$ & $10.4 \pm 1.5$ & $47.0 \pm 0.3$ \\
Soluble protein, \% of CP & $54.8 \pm 2.8$ & $61.2 \pm 6.1$ & $48.7 \pm 2.8$ & $77.4 \pm 1.6$ \\
ADICP, \% of CP & $9.2 \pm 0.4$ & $10.5 \pm 1.3$ & $7.7 \pm 0.8$ & $1.5 \pm 0.1$ \\
NDICP, \% of CP & $11.6 \pm 0.8$ & $15.7 \pm 3.1$ & $11.9 \pm 1.0$ & $3.2 \pm 0.1$ \\
aNDFom, \% of DM & $41.3 \pm 2.7$ & $44.2 \pm 2.2$ & $39.1 \pm 3.8$ & $19.1 \pm 0.8$ \\
30-h uNDFom, \% of aNDFom & $40.8 \pm 1.0$ & $50.3 \pm 2.5$ & $54.6 \pm 2.1$ & - \\
120-h uNDFom, \% of aNDFom & $35.9 \pm 1.0$ & $44.1 \pm 3.1$ & $47.7 \pm 2.4$ & - \\
240-h uNDFom, \% of aNDFom & $23.9 \pm 1.2$ & $40.1 \pm 3.5$ & $44.9 \pm 2.6$ & - \\
ADF, \% of DM & $24.9 \pm 1.8$ & $35.4 \pm 1.8$ & $35.5 \pm 3.2$ & $6.0 \pm 1.2$ \\
Lignin, \% of DM & $2.8 \pm 0.2$ & $7.0 \pm 0.6$ & $7.5 \pm 0.7$ & $2.6 \pm 0.2$ \\
Sugars, \% of DM & $1.5 \pm 0.2$ & $4.3 \pm 1.7$ & $8.2 \pm 0.7$ & $8.4 \pm 2.1$ \\
Starch, \% of DM & $29.4 \pm 3.2$ & $2.4 \pm 0.8$ & $2.4 \pm 0.5$ & $14.7 \pm 2.7$ \\
Ether extract, \% of DM & $3.1 \pm 0.1$ & $3.3 \pm 0.2$ & $2.2 \pm 0.2$ & $3.0 \pm 0.1$ \\
Ash, \% of DM & $2.7 \pm 0.2$ & $8.8 \pm 1.0$ & $10.5 \pm 1.7$ & $5.0 \pm 1.9$ \\
\hline
\end{tabular}

${ }^{1}$ Analyzed values from 10 weekly samples per forage ingredient, 2 samples for fermentation by-product.

${ }^{2} \mathrm{CPE}=$ crude protein equivalent; $\mathrm{ADICP}=$ acid detergent insoluble protein; $\mathrm{NDICP}=$ neutral detergent insoluble protein; aNDFom $=$ NDF analyzed using $\alpha$-amylase and sodium sulfite and corrected for ash content; uNDFom $=$ undegraded NDF

${ }^{3}$ Fermenten, Church and Dwight Inc., Princeton, NJ. 
sodium heparin, and immediately placed on ice. Within $30 \mathrm{~min}$ of collection, samples were centrifuged $(3,000$ $\times g$ for 20 min at $4^{\circ} \mathrm{C}$ ), and plasma was harvested and frozen at $-20^{\circ} \mathrm{C}$ for later analysis. Plasma urea nitrogen (PUN) concentration was determined using an enzymatic colorimetric assay based on a commercial kit (No. 640, Sigma-Aldrich, St. Louis, MO).

All relevant farm, cattle, and diet information were entered into CNCPS version 6.55 for numerical comparisons of $\mathrm{N}$ utilization between treatments. Change in BCS was input as measured, and weight change information for the model was computed by the target growth system (Fox et al., 1999) within the CNCPS. Body weight gain in the CNCPS was assumed to be associated with frame growth; thus, entering observed BW gain for cattle gaining body condition through the lactation cycle will result in overestimation of growth requirements for energy and protein.

\section{Statistical Analyses}

All data were analyzed using SAS version 9.3 (SAS Institute Inc., Cary, NC). Diet chemical composition was analyzed using PROC GLM, and means were compared using the LSMEAN statement. All other data were analyzed using PROC MIXED, with pen as the experimental unit and individual animal as the observational unit (Bello et al., 2016) when individual information was available, as discussed by St-Pierre (2007). For observations containing individual cow information in the form of covariate and repeated weekly measurements (milk, components, ECM, PUN, BW, and BCS), the following model was used:

$$
\begin{aligned}
\mathrm{Y}_{\mathrm{ijklm}}= & \mu+\mathrm{T}_{\mathrm{i}}+\mathrm{W}_{\mathrm{j}}+\mathrm{TW}_{\mathrm{ij}}+\mathrm{P}_{\mathrm{k}: \mathrm{i}} \\
& +\mathrm{BX}_{\mathrm{lik}}+\mathrm{L}_{\mathrm{m}}+\varepsilon_{\mathrm{ijklm}}
\end{aligned}
$$

where $Y_{i j k l m}=$ dependent variable, $\mu=$ overall mean, $T_{i}$ = fixed effect of treatment $\mathrm{i}, \mathrm{W}_{\mathrm{j}}$ = fixed effect of week $\mathrm{j}, \mathrm{TW}_{\mathrm{ij}}=$ fixed interaction of treatment $\mathrm{i}$ and week $\mathrm{j}$, $\mathrm{P}_{\mathrm{k}: \mathrm{i}}=$ random effect of pen $\mathrm{k}$ within treatment $\mathrm{i}$ (error term), $\mathrm{BX}_{\text {lik }}=$ the covariate adjustment for each cow, $\mathrm{L}_{\mathrm{m}}$ $=$ fixed effect of parity, and $\varepsilon_{\mathrm{ijklm}}=$ residual error. Repeated measures were analyzed using an autoregressive structure $[\mathrm{AR}(1)]$ with cow within pen and treatment

\begin{tabular}{|c|c|c|c|}
\hline \multirow[b]{2}{*}{ Ingredient, $\%$ of $\mathrm{DM}$} & \multicolumn{3}{|c|}{$\operatorname{Diet}^{2}$} \\
\hline & $\mathrm{SBM}+\mathrm{U}$ & $\mathrm{SBM}+\mathrm{F}$ & RP-SBM \\
\hline Corn silage & $41.9 \pm 0.1$ & $41.9 \pm 0.1$ & $42.0 \pm 0.1$ \\
\hline Alfalfa silage & $4.9 \pm 0.1$ & $4.9 \pm 0.1$ & $4.9 \pm 0.1$ \\
\hline Alfalfa hay & $8.1 \pm 0.1$ & $8.0 \pm 0.1$ & $8.1 \pm 0.1$ \\
\hline Steam-flaked corn & $12.5 \pm 0.8$ & $12.6 \pm 0.9$ & $12.6 \pm 0.8$ \\
\hline Corn meal & $7.7 \pm 0.7$ & $7.6 \pm 0.8$ & $7.7 \pm 1.0$ \\
\hline Protein premix & $24.9 \pm 0.1$ & $25.0 \pm 0.1$ & $25.0 \pm 0.2$ \\
\hline Soybean meal & $6.98 \pm 0.02$ & $7.2 \pm 0.03$ & $3.57 \pm 0.09$ \\
\hline Wheat middlings & $3.49 \pm 0.01$ & - & - \\
\hline Urea & $0.51 \pm 0.01$ & - & $0.09 \pm 0.01$ \\
\hline Rumen-protected soybean meal ${ }^{3}$ & - & - & $7.14 \pm 0.18$ \\
\hline Fermentation by-product meal ${ }^{4}$ & - & $3.59 \pm 0.01$ & - \\
\hline Dried molasses & $3.68 \pm 0.02$ & $3.61 \pm 0.01$ & $3.56 \pm 0.09$ \\
\hline Soybean hulls & $3.81 \pm 0.18$ & $3.80 \pm 0.15$ & $3.64 \pm 0.06$ \\
\hline Saturated fatty acid $^{5}$ & $1.97 \pm 0.09$ & $1.98 \pm 0.07$ & $1.85 \pm 0.10$ \\
\hline Blood meal with added methionine ${ }^{6}$ & $1.05 \pm 0.01$ & $1.08 \pm 0.01$ & $1.07 \pm 0.03$ \\
\hline Calcium sulfate, dihydrate & $1.05 \pm 0.01$ & - & $1.07 \pm 0.03$ \\
\hline Ground limestone & $0.35 \pm 0.01$ & $1.08 \pm 0.01$ & $0.36 \pm 0.01$ \\
\hline Sodium sesquicarbonate & $0.70 \pm 0.01$ & $0.72 \pm 0.01$ & $0.71 \pm 0.02$ \\
\hline White salt & $0.52 \pm 0.01$ & $0.54 \pm 0.01$ & $0.53 \pm 0.01$ \\
\hline Vitamin and mineral $\operatorname{mix}^{7}$ & $0.79 \pm 0.02$ & $0.79 \pm 0.03$ & $0.80 \pm 0.04$ \\
\hline
\end{tabular}

Table 2. Ingredient composition (mean $\pm \mathrm{SD})^{1}$ of experimental diets

${ }^{1}$ Composition obtained from feed management software and mill mixing information.

${ }^{2} \mathrm{SBM}+\mathrm{U}=$ diet containing soybean meal, wheat middlings, and urea; $\mathrm{SBM}+\mathrm{F}=\operatorname{diet}$ containing soybean meal and fermentation by-product; RP-SBM = diet containing soybean meal and rumen-protected soybean meal.

${ }^{3}$ Soyplus, West Central Cooperative, Ralston, IA.

${ }^{4}$ Fermenten, Church and Dwight Inc., Princeton, NJ.

${ }^{5}$ Energy Booster 100, MSC Company, Dundee, IL.

${ }^{6}$ LysAAMet, Perdue AgriBuisness, Salisbury, MD.

${ }^{7}$ Contained (DM basis) $8.1 \% \mathrm{Ca} ; 0.21 \% \mathrm{P} ; 21.6 \% \mathrm{Mg} ; 0.7 \% \mathrm{~K} ; 1.9 \% \mathrm{~S} ; 0.4 \% \mathrm{Na} ; 79 \mathrm{mg} / \mathrm{kg}$ of Fe; $3,523 \mathrm{mg} /$ $\mathrm{kg}$ of $\mathrm{Zn} ; 1,050 \mathrm{mg} / \mathrm{kg}$ of Cu; $1,355 \mathrm{mg} / \mathrm{kg}$ of $\mathrm{Mn} ; 33 \mathrm{mg} / \mathrm{kg}$ of Se; $68 \mathrm{mg} / \mathrm{kg}$ of Co; $32 \mathrm{mg} / \mathrm{kg}$ of I; $740 \mathrm{kIU} /$ $\mathrm{kg}$ of vitamin A; $207 \mathrm{kIU} / \mathrm{kg}$ of vitamin D; 4,589 IU $/ \mathrm{kg}$ of vitamin E; and 2,550 mg/ $\mathrm{kg}$ of Rumensin, Elanco Animal Health, Greenfield, IN. 
Table 3. Chemical and nutrient composition (mean $\pm \mathrm{SD})^{1}$ of experimental diets

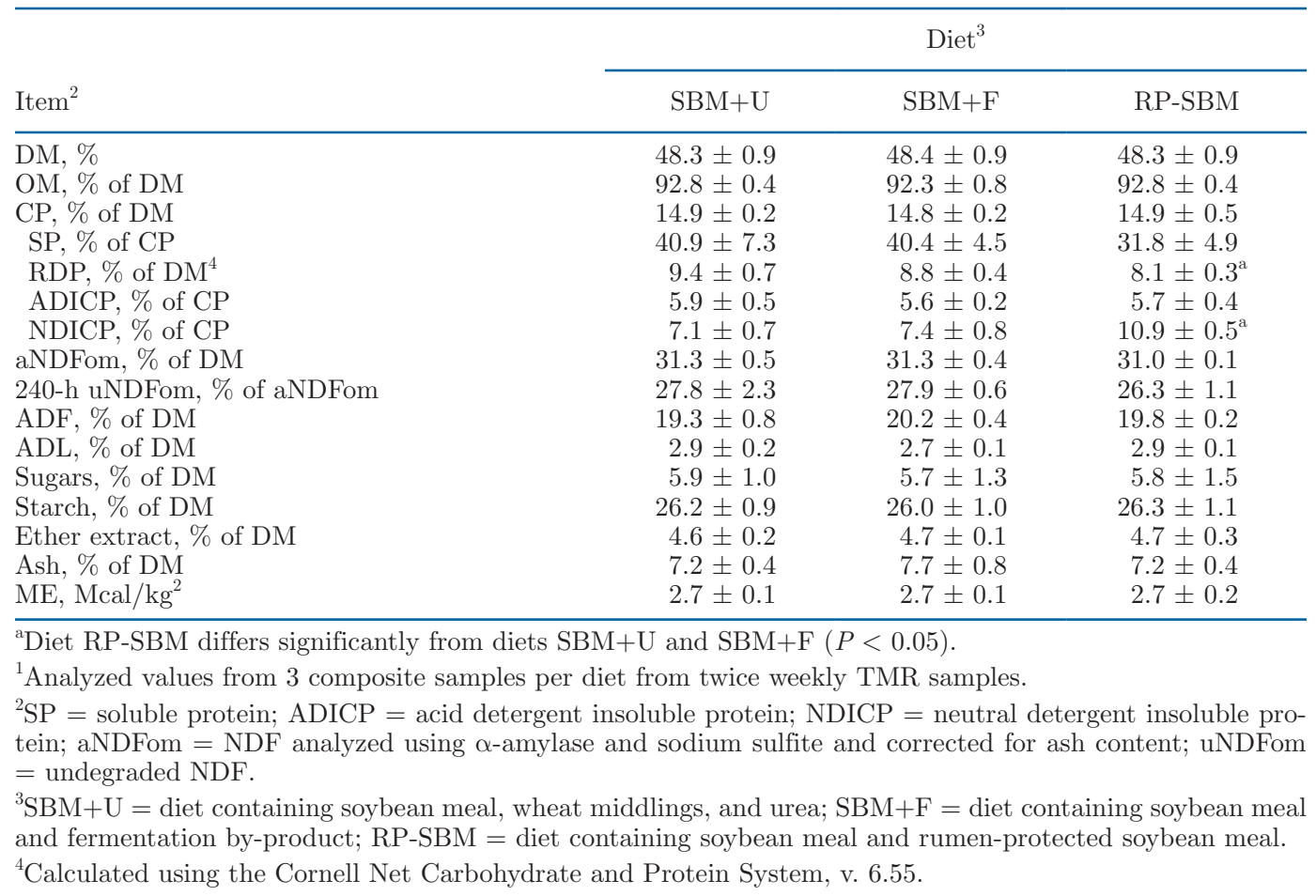

$\left(\mathrm{C}_{\text {l:ik }}\right)$ as the subject. For variables containing pen-level repeated measurements (intake and digestibility data), terms corresponding to individual cow information were removed, and covariate adjustment was applied at the pen level. Statistical analysis of non-repeated measures (BW change and BCS change) did not contain week or covariate adjustments. In all statistical models for animal performance, degrees of freedom were calculated using the Kenward-Roger option to account for any imbalance from missing observations. Nine cows left the experimental pens throughout the trial for health or management reasons $(2,4$, and 3 cows, respectively, from $\mathrm{SBM}+\mathrm{U}, \mathrm{SBM}+\mathrm{F}$, and RP-SBM). These cows were excluded from the analysis for the duration of the absence and, if returned to pens, were evaluated for re-inclusion after $2 \mathrm{wk}$, if milk production indicated adequate recovery. Covariate-adjusted treatment means were determined using the least squares means statement and were compared using Fisher's protected least significant difference. Statistical significance was considered at $P \leq 0.05$, and trends were considered at $0.05<P \leq 0.10$.

\section{RESULTS AND DISCUSSION}

\section{Diets and Milk Performance}

Corn silage fed during the trial averaged $41.3 \%$ aNDFom, 24.9\% ADF, and 29.4\% starch, and did not vary appreciably for the duration of the trial (Table 1). Alfalfa silage averaged $44.2 \%$ aNDFom, $35.4 \%$ ADF, and $17.1 \% \mathrm{CP}$, although $\mathrm{CP}$ decreased in the middle portion of the trial, reaching a nadir of $15 \%$ in wk 7 (Supplemental Figure S1, https://doi.org/10.3168/jds .2019-17744). Alternatively, alfalfa hay maintained a slightly greater-than-average $\mathrm{CP}$ concentration in wk 4 to 8 , reaching a peak $\mathrm{CP}$ concentration of $21.1 \%$ in wk 8 , so no diet adjustments were deemed necessary to maintain desired ration CP. Experimental diets were formulated to be isonitrogenous and isoenergetic (Table 3). Using the measured chemical composition and intakes, calculated RDP using CNCPS (v. 6.55) was decreased in RP-SBM compared with the $\mathrm{SBM}+\mathrm{U}$ and $\mathrm{SBM}+\mathrm{F}$ diets $(7.5$ vs. 9.0 and $8.5 \%$ of $\mathrm{DM}$, respectively; $P<0.05)$. Consequently, inclusion of rumen-protected soybean meal in RP-SBM resulted in increased neutral detergent insoluble CP (10.9 vs. 7.1 and $7.4 \%$ of $\mathrm{CP}$ for diets RP-SBM, SBM+U, and $\mathrm{SBM}+\mathrm{F}$, respectively; $P=0.03)$. These differences in ruminal protein degradability were intended, given the diet formulation and expected mode of action of the fermentation by-product. All other analyzed nutrients were not different between diets $(P>0.05$; Table 2$)$.

Cows fed $\mathrm{SBM}+\mathrm{F}$ had increased intake and $\mathrm{ECM}$ compared with cows fed SBM+U and RP-SBM $(P<$ 0.05; Table 4, Figure 1). Milk yield was increased in cows fed $\mathrm{SBM}+\mathrm{F}$ compared with cows fed $\mathrm{SBM}+\mathrm{U}$ $(42.5 \mathrm{~kg} / \mathrm{d}$ vs. 40.7 , respectively; $P<0.05)$, although 
Table 4. Effect of treatment on covariate-adjusted LSM for DMI and milk performance in lactating dairy cattle fed 3 different protein supplements

\begin{tabular}{lccccc}
\hline & \multicolumn{3}{c}{ Diet $^{1}$} & & $P^{\text {-value }}{ }^{2}$ \\
\cline { 2 - 3 } \cline { 5 - 6 } Item & SBM+U & SBM+F & RP-SBM & SEM & Diet \\
\hline DMI, kg/d & $26.9^{\mathrm{b}}$ & $28.3^{\mathrm{a}}$ & $26.7^{\mathrm{b}}$ & 0.4 & 0.03 \\
Milk yield, kg/d & $40.7^{\mathrm{b}}$ & $42.5^{\mathrm{a}}$ & $41.6^{\mathrm{ab}}$ & 0.5 & 0.05 \\
ECM, kg/d & $43.6^{\mathrm{b}}$ & $45.3^{\mathrm{a}}$ & $43.7^{\mathrm{b}}$ & 0.4 & 0.05 \\
Milk fat, \% & 3.82 & 3.73 & 3.72 & 0.05 & 0.30 \\
Milk fat, kg/d & 1.62 & 1.64 & 1.61 & 0.02 & 0.39 \\
Milk true protein, \% & 3.11 & 3.17 & 3.08 & 0.03 & 0.11 \\
Milk true protein, kg/d & $1.31^{\mathrm{a}}$ & $1.38^{\mathrm{b}}$ & $1.33^{\mathrm{a}}$ & 0.01 & 0.02 \\
Milk urea N, mg/dL & $7.1^{\mathrm{a}}$ & $6.7^{\mathrm{b}}$ & $6.2^{\mathrm{c}}$ & 0.1 & $<0.01$ \\
Plasma urea N, mg/dL & $9.5^{\mathrm{a}}$ & $8.5^{\mathrm{b}}$ & $8.3^{\mathrm{b}}$ & 0.2 & 0.01 \\
Feed efficiency & 1.60 & 1.59 & 1.61 & 0.02 & 0.77 \\
\hline
\end{tabular}

${ }^{a-c}$ Within a row, means with different superscripts differ $(P<0.05)$.

${ }^{1} \mathrm{SBM}+\mathrm{U}=$ diet containing soybean meal, wheat middlings, and urea; $\mathrm{SBM}+\mathrm{F}=$ diet containing soybean meal and fermentation by-product; RP-SBM = diet containing soybean meal and rumen-protected soybean meal. Pen is the experimental unit for all analyses.

${ }^{2}$ Week effect $(P<0.01)$ present for all parameter estimates, and week $\times$ treatment effect $(P<0.01)$ present for all items except plasma urea $\mathrm{N}(\mathrm{mg} / \mathrm{dL})$.

${ }^{3} \mathrm{ECM} / \mathrm{DMI}$.

milk yield for cows fed SBM+F and RP-SBM were not different $(P=0.21)$. Milk fat percent and yield were not different among any of the treatments. The magnitude and direction of the observed differences in DMI and ECM were similar to those reported in an omasal flow study with the same fermentation by-product meal (Fessenden et al., 2019a) compared with cows fed a control diet similar to the $\mathrm{SBM}+\mathrm{U}$ diet in this study. We anticipated that the fermentation by-product meal in $\mathrm{SBM}+\mathrm{F}$ would reduce dietary $\mathrm{CP}$ degradation in the rumen, allowing cows fed $\mathrm{SBM}+\mathrm{F}$ to have increased flow of MP to the small intestine relative to cows fed SBM+U. Given the similarity of diets, cows, and management, a similar protein-sparing mechanism, as reported by Fessenden et al. (2019a), could explain the observed milk production results reported here.

Previous research with similar fermentation by-products demonstrated few to no benefits, compared with a urea control (Broderick et al., 2000). The diets in that study had relatively small amounts of dietary protein supplied by concentrate feeds other than the fermentation by-product, possibly resulting in low true soluble and degradable protein balance in the urea control and fermentation by-product treatments. As such, soybean meal supplementation produced an expected positive response in milk production, compared with a control diet containing wheat middlings and urea (Broderick et al., 2000). Recycling of urea $\mathrm{N}$ and endogenous secretions might provide additional rumen-available $\mathrm{N}$, although the ability of microbes to utilize these sources for rapid, efficient growth is likely lower than that of preformed AA of dietary origin (Atasoglu et al., 2001; Wallace et al., 2001). In diets averaging approximately
$20 \%$ CP, Penner et al. (2009) observed a numerical increase in milk yield and milk energy output when the same fermentation by-product was fed in low-sugar diets compared with a canola meal control. Direction and magnitude of the effect in the Penner et al. (2009) study were similar to observed responses in the current study. These results indicate that the ability of the fermentation by-product to increase MP flow, and therefore milk production, might be dependent on positive rumen peptide and degradable protein supply.

As the trial progressed, ECM in cows fed $\mathrm{SBM}+\mathrm{U}$ and RP-SBM decreased (Figure 2) to a nadir at wk 7, the same week that alfalfa silage $\mathrm{CP}$ content reached its nadir (Supplemental Figure S1; https://doi.org/ 10.3168/jds.2019-17744). It is possible that a similar protein-sparing effect of the fermentation by-product reported by Fessenden et al. (2019a,b) might have allowed cows fed $\mathrm{SBM}+\mathrm{F}$ to maintain MP supply despite a possible decrease in soluble $\mathrm{N}$ from alfalfa silage. Use of ECM to evaluate production differences takes into account the animal's ability to utilize substrate and metabolites in a variety of milk synthesis pathways, depending on which nutrient is most limiting (Lobley, 2007; Lemosquet et al., 2010). This is demonstrated in cows fed RP-SBM: milk yield was not different from cows fed $\mathrm{SBM}+\mathrm{U}$ or RP-SBM; however, milk protein yield was significantly lower in the cows fed the RP-SBM diet (1.38 vs. $1.31 \mathrm{~kg} / \mathrm{d}$ for cows fed $\mathrm{SBM}+\mathrm{F}$ and RPSBM, respectively). The RP-SBM diet was formulated to be sufficient in rumen-degradable $\mathrm{N}$, with inclusion of rumen-protected soybean meal to allow for increased passage of intestinally available RUP; therefore, cows fed $\mathrm{SBM}+\mathrm{F}$ and RP-SBM were expected to perform in 


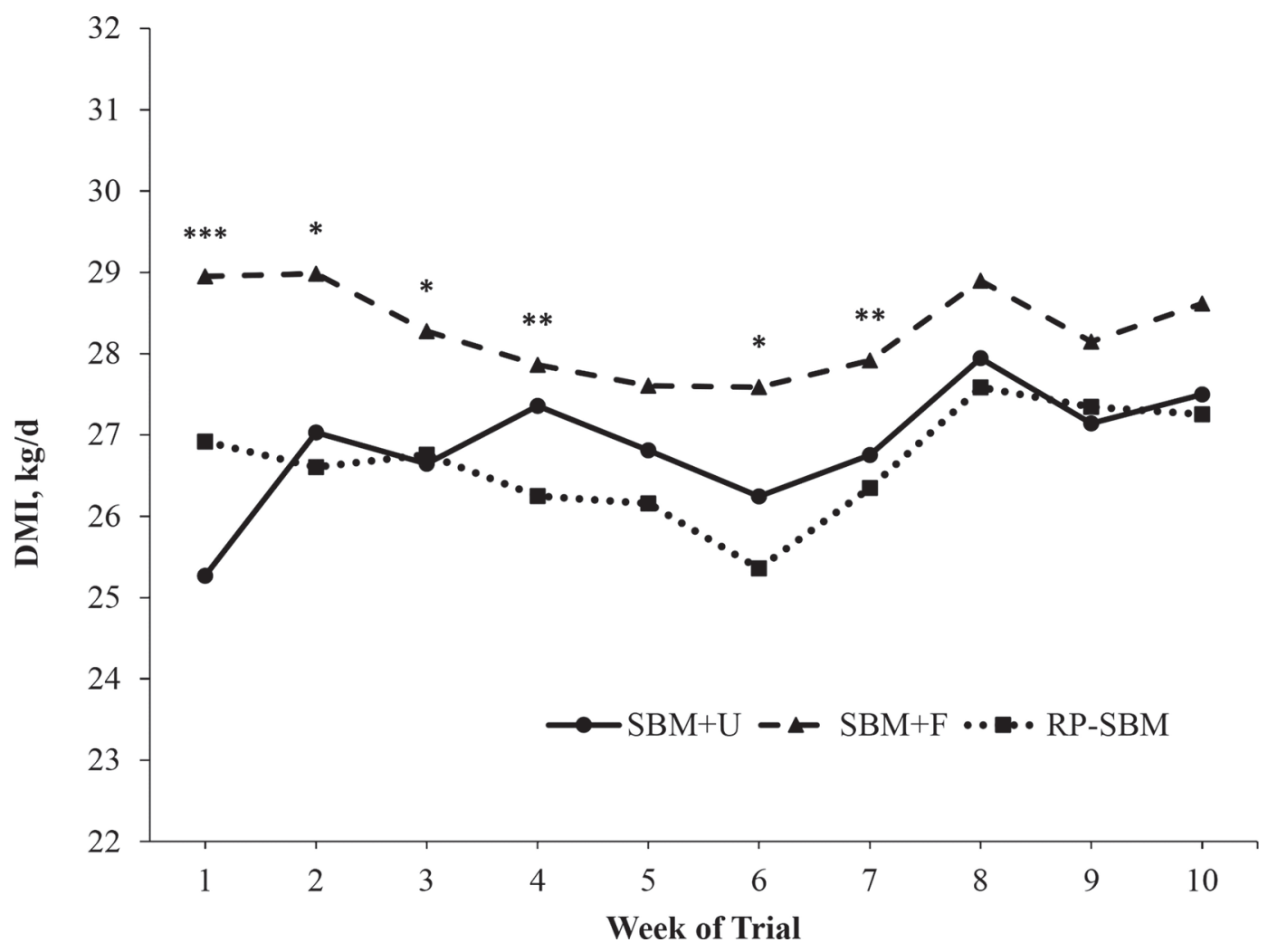

Figure 1. Effect of treatment on covariate-adjusted LSM for DMI by week of trial. Treatments were SBM+U = diet containing soybean meal, wheat middlings, and urea; $\mathrm{SBM}+\mathrm{F}=$ diet containing soybean meal and fermentation by-product; RP-SBM $=$ diet containing soybean meal and rumen-protected soybean meal. Week and week $\times$ treatment interaction effects $(P<0.01)$; SEM $=0.4$. Weeks labeled with $*$ denote treatment effect $(P<0.05)$ between $\mathrm{SBM}+\mathrm{F}$ and other treatments. Weeks labeled with $* *$ denote treatment effect $(P \leq 0.05)$ between $\mathrm{SBM}+\mathrm{F}$ and RP-SBM. Weeks labeled with $* * *$ denote all treatments differed $(P \leq 0.05)$ from each other.

a similar manner. Given the relatively lower milk yield in cows fed RP-SBM, it is possible that RDP balance was insufficient to promote adequate microbial protein synthesis and thus MP supply. In separate reviews of soybean meal replacement with RUP supplements, Santos et al. (1998) and Ipharraguerre and Clark (2005) found inconsistent increases in milk performance, and concluded that RDP balance can be limiting in many diets with high RUP supplementation, although neither analysis sought to control for the possibility of ME limitations in the data sets. Lower-than-expected intestinal digestibility of rumen-protected soybean meal might also contribute to insufficient MP compared with $\mathrm{SBM}+\mathrm{U}$ and might have limited production in cows fed RP-SBM.

Treatment strongly influenced MUN and PUN concentrations in this study (Table 4). Milk urea nitrogen was greatest in cows fed $\mathrm{SBM}+\mathrm{U}$, followed by cows fed SBM+F and RP-SBM $(7.1,6.7$, and $6.2 \mathrm{mg} / \mathrm{dL}$ for cows fed $\mathrm{SBM}+\mathrm{U}, \mathrm{SBM}+\mathrm{F}$, and RP-SBM, respectively). Plasma urea nitrogen followed the same trend. Responses of this sort have been well documented be- fore in low-CP diets (Colmenero and Broderick, 2006; Brito and Broderick, 2007). In a study investigating the effects of rumen-available $\mathrm{N}$ in the form of urea, Broderick and Reynal (2009) demonstrated a clear, linear response of MUN and PUN to increased RDP. In the present study, steadily decreasing RDP in the form of true protein similarly resulted in lower MUN and PUN. In a meta-analysis of omasal sampling studies, Broderick et al. (2010) suggested that diets containing $14.7 \%$ $\mathrm{CP}$ and $10.6 \%$ RDP resulted in ruminal $\mathrm{N}$ balance of 0 . Compared with the results reported in Fessenden et al. $(2019 a, b)$, the inclusion of fermentation by-product had an opposite effect on urea $\mathrm{N}$ concentrations. This is consistent with the hypothesis of a protein-sparing effect of fermentation by-product on degradable protein. Fessenden et al. (2019a) reported a decrease in ruminal $\mathrm{CP}$ degradation, yet greater ammonia accumulation occurred, indicating possible shifts in the fate of soluble AA and peptides between diets. Because peptide uptake and transport is a rate-limiting step in protein degradation (Wallace et al., 1990), accumulation of AA and peptides in the rumen fluid might simultaneously 


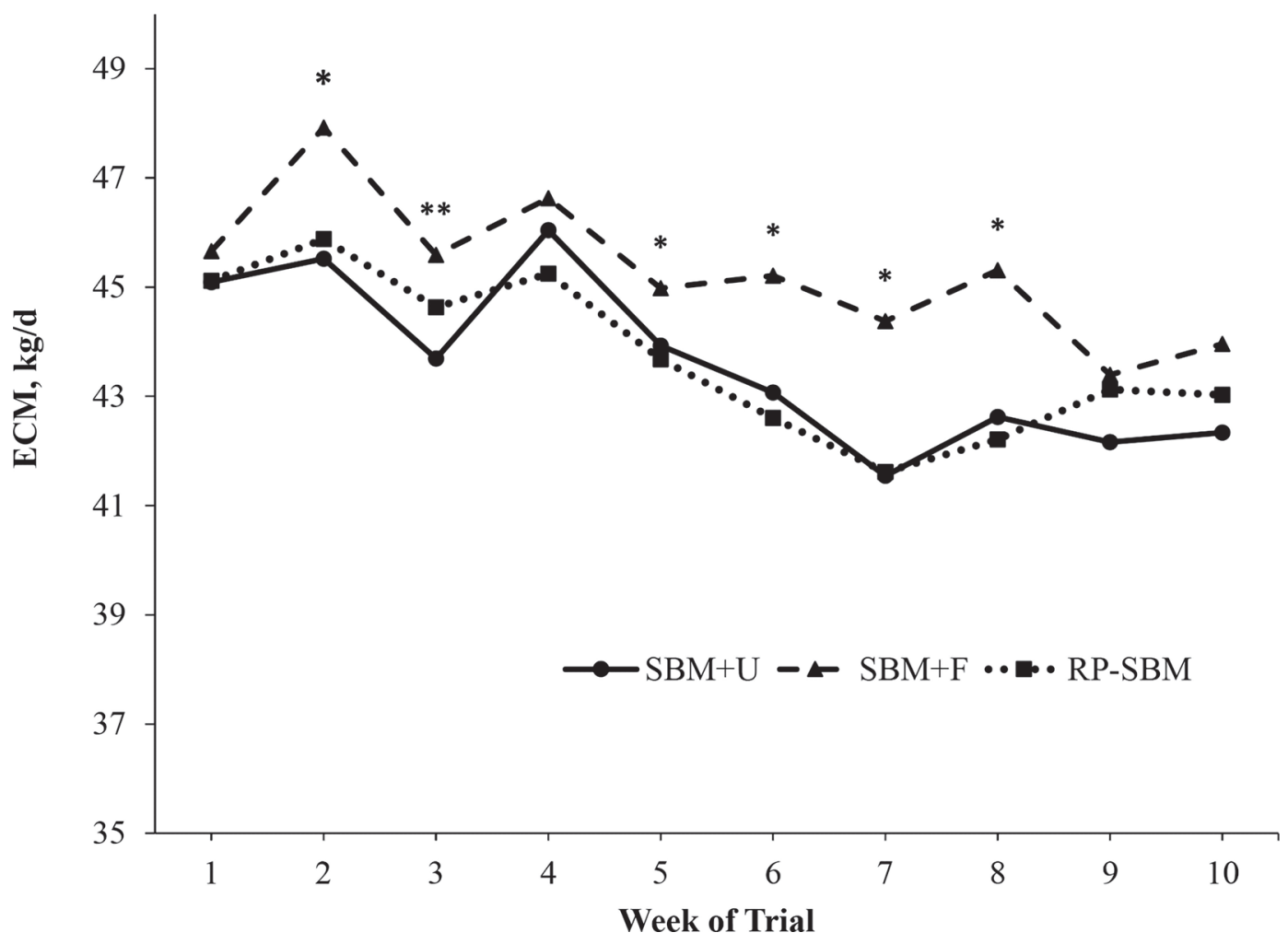

Figure 2. Effect of treatment on covariate-adjusted LSM for ECM by week of trial. Treatments were SBM+U = diet containing soybean meal, wheat middlings, and urea; SBM $+\mathrm{F}=$ diet containing soybean meal and fermentation by-product; RP-SBM $=$ diet containing soybean meal and rumen-protected soybean meal. Week and week $\times$ treatment interaction effects $(P<0.01)$; SEM $=0.4$. Weeks labeled with $*$ denote treatment effect $(P \leq 0.05)$ between $\mathrm{SBM}+\mathrm{F}$ and all other treatments. Weeks labeled with ${ }^{* *}$ denote treatment effect $(P \leq 0.05)$ between $\mathrm{SBM}+\mathrm{F}$ and $\mathrm{SBM}+\mathrm{U}$.

allow for increased rumen $\mathrm{NH}_{3}-\mathrm{N}$ accumulation and increased RUP flow from soluble amino nitrogen. This is likely to occur when relatively greater numbers of hyper-ammonia-producing bacteria are present (Russell et al., 1988). A key difference between the omasal study (Fessenden et al., 2019a,b) and the current study is the use of monensin in this study. Hyper-ammoniaproducing bacteria have been shown to be sensitive to monensin (Yang and Russell, 1993), and suppression of these microbes would allow for concomitant decreased MUN and PUN levels. Further investigation of possible fermentation by-product and monensin interactions might be warranted.

\section{Body Weight, Condition Score, and Total-Tract Nutrient Digestibility}

Treatments did not have any appreciable effects on body weight, condition score, or rate of BW and BCS change (Table 5; Figure 3). Recorded BW and BCS change was consistent with normal temporal changes in mid-lactation dairy cattle. (Waltner et al., 1993; Roche et al., 2009). Total-tract apparent nutrient digestibil- ity was affected by treatment (Table 6). Daily DMI reported are from sampling weeks only. Intake of $\mathrm{uN}$ DFom was different among diets, with 2.34, 2.48, and $2.15 \mathrm{~kg} / \mathrm{d}$ uNDFom consumed for cows fed SBM+U, $\mathrm{SBM}+\mathrm{F}$, and RP-SBM, respectively $(P<0.01)$. These differences are likely due to the combination of small numerical differences in intake and uNDFom concentration between diets. Rumen-degradable protein intake was lower in cows fed RP-SBM relative to cows fed $\mathrm{SBM}+\mathrm{U}$ and $\mathrm{SBM}+\mathrm{F}(2.16$ vs. 2.57 and $2.51 \mathrm{~kg}$ of $\mathrm{RDP}$ intake/d, respectively; $P<0.01)$. Because microbial contribution to fecal nutrients was not quantified, all total-tract digestibilities are treated as apparent. Dry matter digestibility tended to be lower in cows fed $\mathrm{SBM}+\mathrm{F}$ relative to cows fed $\mathrm{SBM}+\mathrm{U}$ or RP-SBM $(P$ $=0.09)$, and $\mathrm{OM}$ digestibility increased in cows fed RP-SBM compared with cows fed SBM+F (73.8 and $76.7 \%$, respectively; $P<0.05$ ), although apparent DM and $\mathrm{OM}$ digestion is of limited biologic significance due to variation in microbial and metabolic fecal contributions (Van Soest, 2015). Total-tract digestion of aNDFom was reduced in cows fed $\mathrm{SBM}+\mathrm{F}$ compared with cows fed RP-SBM $(P<0.01)$, although no significant 
difference was observed between cows fed SBM+U compared with cows fed SBM+F or RP-SBM. Similar directionality and magnitude of differences were observed with total-tract digestion of the potentially degradable NDF fraction; however, no significant differences were detected. These results indicate that digestion of NDF in the total tract was not positively affected by increased dietary supply of RDP. Results observed in this study were similar to those reported by Brito and Broderick (2007) in cattle fed canola compared with a urea control, whereas increased RDP did not increase total-tract NDF digestion. In an omasal study with processed compared with unprocessed canola meal, increased RDP had no effect on ruminal or total-tract NDF digestion, although increased CP level in the diet had negative effects on NDF digestion (Mutsvangwa et al., 2016). The lack of response to increased RDP was likely a result of positive rumen $\mathrm{N}$ balance in most of these studies. When cattle were fed diets formulated to be deficient in rumen $\mathrm{N}$, total-tract NDF digestion was decreased (Higgs, 2014). Digestion of NDF is influenced not only by RDP balance but also by many other factors, a principal one being intake. In the current study, it is likely that the increased intake observed in cows fed $\mathrm{SBM}+\mathrm{F}$ resulted in increased passage rate from the rumen, thus reducing the extent of digestion (Waldo et al., 1972; Van Soest, 2015). Interestingly, NDF degraded per gram of RDP intake was increased in cows fed RP-SBM compared with cows fed $\mathrm{SBM}+\mathrm{U}$ and SBM-F (2.03 vs. 1.70 and $1.68 \mathrm{~g}$ of NDF degraded/g of RDP, respectively). Although this is not a commonly used metric, it recognizes the trade-off between ruminal NDF digestion and rumen degradation of protein, whereas a high extent of ruminal NDF digestion due to slower passage rate would typically result in increased dietary protein degradation due to increased retention time of feeds.

Cattle, feed, and milk output information were entered into CNCPS version 6.55, to perform numerical comparisons of estimated $\mathrm{N}$ excretion and nitrogen utilization for each diet (Supplemental Table S1, https: //doi.org/10.3168/jds.2019-17744). Cows fed SBM+F had numerically greater intake of $\mathrm{N}$ compared with cows fed $\mathrm{SBM}+\mathrm{U}$ and RP-SBM. Fecal $\mathrm{N}$ was predicted to be numerically greater in $\mathrm{SBM}+\mathrm{F}$, likely due to increased OM intake (Higgs et al., 2012). Overall milk nitrogen efficiency averaged approximately $32 \%$, which is higher than the mean, yet well within the range reported by Huhtanen and Hristov (2009). When milk nitrogen efficiency is calculated without the contribution of intake from forage $\mathrm{N}$, we must recognize the fact that non-ruminant species are not typically fed forage-based diets. Although somewhat imprecise, estimates such as this might provide a more meaningful comparison to the 50 to $60 \% \mathrm{~N}$ retention seen with non-ruminant species (Campbell et al., 1984; Noblet et al., 1987; Sakomura et al., 2007). Further, inclusion of by-products from human food production in ruminant production systems can reduce competition for resources with human-edible food production (Karlsson et al., 2018; Wilkinson and Lee, 2017). In this study, cows fed a by-product protein source were able to maintain high levels of ECM and milk yield output. When these results are considered together with the reduced CP degradation reported by Fessenden et al. (2019a,b), is it possible to see how inclusion of commercial fermentation by-product could play a role in improving efficiency of animal protein production.

\section{CONCLUSIONS}

In this study, cows fed a commercial fermentation by-product produced more milk and milk protein yield and ECM than did cows fed a soybean meal, wheat middlings, and urea control diet, or rumen-protected soybean meal. The performance responses observed in this study are consistent with previous research with the same fermentation by-product that reported a reduction in dietary protein degradation and increased AA flow to the small intestine. It was anticipated that cows fed fermentation by-product and soybean meal would perform similarly to those fed protected soybean meal; however, cattle on the diet containing protected soybean meal performed similarly to those fed the soy-

Table 5. Effect of rumen-degradable protein source on body weight and condition score in lactating dairy cattle

\begin{tabular}{|c|c|c|c|c|c|c|c|}
\hline Item & \multicolumn{3}{|c|}{$\operatorname{Diet}^{1}$} & SEM & \multicolumn{3}{|c|}{$P$-value } \\
\hline Body weight, $\mathrm{kg}^{2}$ & 721 & 719 & 723 & 2.8 & 0.68 & $<0.01$ & 0.97 \\
\hline Body weight change, $\mathrm{kg} /$ week & 3.4 & 3.8 & 4.0 & 0.90 & 0.74 & - & - \\
\hline Condition score change, score/month & 0.03 & 0.05 & 0.06 & 0.01 & 0.32 & - & - \\
\hline
\end{tabular}

${ }^{1} \mathrm{SBM}+\mathrm{U}=$ diet containing soybean meal, wheat middlings, and urea; $\mathrm{SBM}+\mathrm{F}=$ diet containing soybean meal and fermentation by-product; $\mathrm{RP}-\mathrm{SBM}=$ diet containing soybean meal and rumen-protected soybean meal. Pen is the experimental unit for all analyses.

${ }^{2}$ Covariate-adjusted LSM. 
Table 6. Effect of rumen-degradable protein source on apparent total-tract nutrient digestion

\begin{tabular}{|c|c|c|c|c|c|}
\hline \multirow[b]{2}{*}{ Item $^{1}$} & \multicolumn{3}{|c|}{$\operatorname{Diet}^{2}$} & \multirow[b]{2}{*}{ SEM } & \multirow[b]{2}{*}{$P$-value } \\
\hline & $\mathrm{SBM}+\mathrm{U}$ & $\mathrm{SBM}+\mathrm{F}$ & RP-SBM & & \\
\hline \multicolumn{6}{|l|}{ Intake, $\mathrm{kg} / \mathrm{d}$} \\
\hline DM & 27.8 & 28.1 & 27.0 & 0.5 & 0.28 \\
\hline $\mathrm{OM}$ & 25.7 & 25.8 & 25.1 & 0.4 & 0.44 \\
\hline aNDFom & 8.67 & 8.78 & 8.35 & 0.14 & 0.15 \\
\hline pdNDF & 6.34 & 6.30 & 6.21 & 0.10 & 0.68 \\
\hline uNDFom & $2.34^{\mathrm{b}}$ & $2.48^{\mathrm{c}}$ & $2.15^{\mathrm{a}}$ & 0.04 & $<0.01$ \\
\hline $\mathrm{RDP}^{3}$ & $2.57^{\mathrm{a}}$ & $2.51^{\mathrm{a}}$ & $2.16^{\mathrm{b}}$ & 0.04 & $<0.01$ \\
\hline Starch & $6.86^{\mathrm{a}}$ & $6.85^{\mathrm{a}}$ & $6.39^{\mathrm{b}}$ & 0.11 & 0.03 \\
\hline \multicolumn{6}{|c|}{ Apparent total-tract digestion, $\%$} \\
\hline DM & 71.2 & 70.3 & 72.7 & 0.7 & 0.09 \\
\hline $\mathrm{OM}$ & $74.6^{\mathrm{ab}}$ & $73.8^{\mathrm{a}}$ & $76.7^{\mathrm{b}}$ & 0.6 & 0.02 \\
\hline aNDFom & $50.3^{\mathrm{ab}}$ & $47.9^{\mathrm{a}}$ & $52.4^{\mathrm{b}}$ & 0.9 & 0.02 \\
\hline pdNDF & 68.8 & 66.8 & 70.6 & 1.2 & 0.14 \\
\hline Starch & 99.2 & 99.2 & 99.3 & 0.2 & 0.96 \\
\hline $\mathrm{NDFD} / \mathrm{RDP}^{4}$ & $1.70^{\mathrm{a}}$ & $1.68^{\mathrm{a}}$ & $2.03^{\mathrm{b}}$ & 0.03 & $<0.01$ \\
\hline
\end{tabular}

${ }^{a-c}$ Within a row, means with different superscripts differ $(P<0.05)$.

${ }^{1}$ aNDFom $=$ NDF analyzed using $\alpha$-amylase and sodium sulfite and corrected for ash content; pdNDF $=$ potentially digestible NDF; uNDFom = undegraded NDF; NDFD = NDF digestibility.

${ }^{2} \mathrm{SBM}+\mathrm{U}=$ diet containing soybean meal, wheat middlings, and urea; $\mathrm{SBM}+\mathrm{F}=$ diet containing soybean meal and fermentation by-product; RP-SBM = diet containing soybean meal and rumen-protected soybean meal.

Pen is the experimental unit for all analyses.

${ }^{3}$ Calculated using the Cornell Net Carbohydrate and Protein System, v. 6.55.

${ }^{4} \mathrm{Kg}$ of aNDFom digested per $\mathrm{kg}$ of rumen-degradable protein intake.

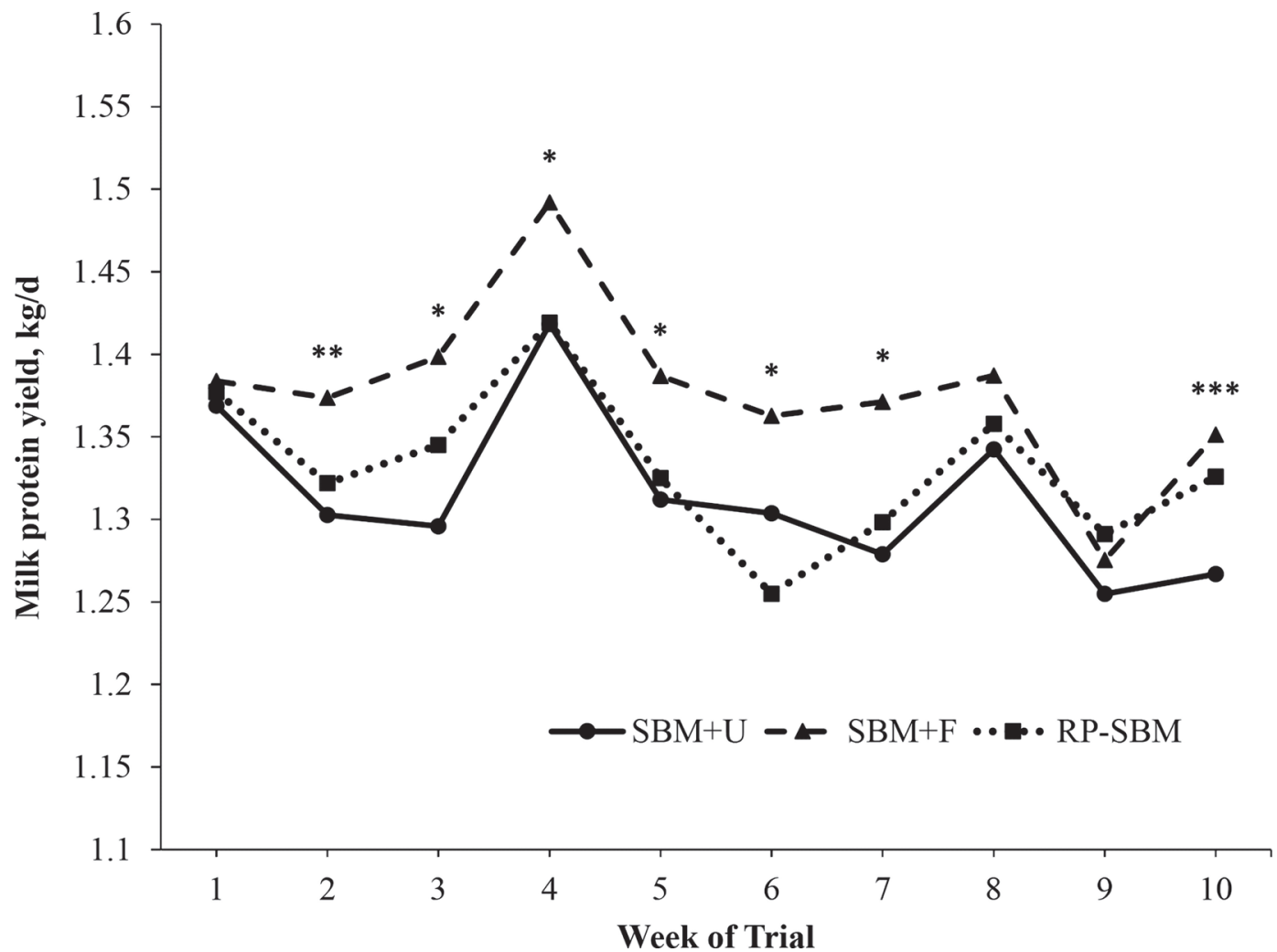

Figure 3. Effect of treatment on covariate-adjusted LSM for milk protein yield by week of trial. Treatments were SBM $+\mathrm{U}=$ diet containing soybean meal, wheat middlings, and urea; $\mathrm{SBM}+\mathrm{F}=$ diet containing soybean meal and fermentation by-product; RP-SBM $=$ diet containing soybean meal and rumen-protected soybean meal. Week and week $\times$ treatment interaction effects $(P<0.01) ;$ SEM $=0.01$. Weeks labeled with * denote treatment effect $(P \leq 0.05)$ between $\mathrm{SBM}+\mathrm{F}$ and other treatments. Weeks labeled with ** denote treatment effect $(P \leq 0.05)$ between $\mathrm{SBM}+\mathrm{F}$ and $\mathrm{SBM}+\mathrm{U}$. Weeks labeled with $* * *$ denote treatment effect $(P \leq 0.05)$ between $\mathrm{SBM}+\mathrm{U}$ and all other treatments. 
bean meal, wheat middlings, and urea control. Body weight and condition score change were unaffected by diet. Total-tract digestion of NDF was slightly reduced with fermentation by-product inclusion, likely due to an increase in DM intake. Results indicate that the commercial fermentation by-product might be useful be used in diets containing adequate RDP to increase milk performance in lactating dairy cattle.

\section{ACKNOWLEDGMENTS}

The authors thank Arm and Hammer Animal Nutrition (Princeton, NJ) for funding support; M. Dineen, A. Zontini, and multiple undergraduate assistants (Cornell University, Ithaca, NY) for helping with sample collection, processing, and analysis; and the research staff and farm crew at the Cornell University Ruminant Center (Harford, NY), especially W. Prokop, L. Furman, and M. Dawson. Portions of this manuscript appear in S. Fessenden's PhD dissertation (Fessenden, 2016). The authors declare that they have no conflicts of interest.

\section{REFERENCES}

Atasoglu, C., C. J. Newbold, and R. J. Wallace. 2001. Incorporation of $[15 \mathrm{~N}]$ ammonia by the cellulolytic ruminal bacteria Fibrobacter succinogenes BL2, Ruminococcus albus $\mathrm{SY} 3$, and Ruminococcus flavefaciens 17. Appl. Environ. Microbiol. 67:2819-2822. https://doi .org/10.1128/AEM.67.6.2819-2822.2001.

Bello, N. M., M. Kramer, R. J. Tempelman, W. W. Stroup, N. R. StPierre, B. A. Craig, L. J. Young, and E. E. Gbur. 2016. On recognizing the proper experimental unit in animal studies in the dairy sciences. J. Dairy Sci. 99:8871-8879. https://doi.org/10.3168/jds .2016-11516.

Brito, A. F., and G. A. Broderick. 2007. Effects of different protein supplements on milk production and nutrient utilization in lactating dairy cows. J. Dairy Sci. 90:1816-1827. https://doi.org/10 $.3168 /$ jds.2006-558.

Broderick, G. A. 2017. Review: Optimizing ruminant conversion of feed protein to human food protein. Animal 12:1722-1734. https:/ /doi.org/10.1017/S1751731117002592.

Broderick, G. A., N. De Leon, and Y. Nakamura. 2000. Potential of fermentation byproducts as nitrogen supplements for lactating dairy cows. J. Dairy Sci. 83:2548-2556. https://doi.org/10.3168/ jds.S0022-0302(00)75147-2.

Broderick, G. A., P. Huhtanen, S. Ahvenjärvi, S. M. Reynal, and K. J. Shingfield. 2010. Quantifying ruminal nitrogen metabolism using the omasal sampling technique in cattle-Meta-analysis. J. Dairy Sci. 93:3216-3230. https://doi.org/10.3168/jds.2009-2989.

Broderick, G. A., and S. M. Reynal. 2009. Effect of source of rumendegraded protein on production and ruminal metabolism in lactating dairy cows. J. Dairy Sci. 92:2822-2834. https://doi.org/10 $.3168 /$ jds.2008-1865.

Campbell, R. G., M. R. Taverner, and D. M. Curic. 1984. Effect of feeding level and dietary protein content on the growth, body composition and rate of protein deposition in pigs growing from 45 to $90 \mathrm{~kg}$. Anim. Sci. 38:233-240. https://doi.org/10.1017/ S0003356100002221.

Castillo, A. R., E. Kebreab, D. E. Beever, and J. France. 2000. A review of efficiency of nitrogen utilization in lactating dairy cows and its relationship with environmental pollution. J. Anim. Feed Sci. 9:1-32. https://doi.org/10.22358/jafs/68025/2000.

Colmenero, J. J., and G. A. Broderick. 2006. Effect of dietary crude protein concentration on milk production and nitrogen utilization in lactating dairy cows. J. Dairy Sci. 89:1704-1712. https://doi .org/10.3168/jds.S0022-0302(06)72238-X.

Cotta, M. A., and J. B. Russell. 1982. Effect of peptides and amino acids on efficiency of rumen bacterial protein synthesis in continuous culture. J. Dairy Sci. 65:226-234. https://doi.org/10.3168/jds .S0022-0302(82)82181-4.

Fessenden, S. W. 2016. Amino acid supply in dairy cattle. PhD dissertation, Department of Animal Science, Cornell University, Ithaca, NY. https://ecommons.cornell.edu/handle/1813/45365.

Fessenden, S. W., A. Foskolos, T. J. Hackmann, D. A. Ross, E. Block, and M. E. Van Amburgh. 2019a. Effects of a commercial fermentation byproduct or urea on milk production, rumen metabolism, and omasal flow of nutrients in lactating dairy cattle. J. Dairy Sci. 102:3023-3035. https://doi.org/10.3168/jds.2018-15447.

Fessenden, S. W., T. J. Hackmann, D. A. Ross, E. Block, A. Foskolos, and M. E. Van Amburgh. 2019b. Rumen digestion kinetics, microbial yield, and omasal flows of nonmicrobial, bacterial, and protozoal amino acids in lactating dairy cattle fed fermentation by-products or urea as a soluble nitrogen source. J. Dairy Sci. 102:3036-3052. https://doi.org/10.3168/jds.2018-15448.

Firkins, J. L. 1996. Maximizing microbial protein synthesis in the rumen. J. Nutr. 126(Suppl. 4):1347S-1354S. https://doi.org/10 .1093/jn/126.suppl_4.1347S.

Fox, D. G., M. E. Van Amburgh, and T. P. Tylutki. 1999. Predicting requirements for growth, maturity, and body reserves in dairy cattle. J. Dairy Sci. 82:1968-1977. https://doi.org/10.3168/jds.S0022 -0302(99)75433-0.

Hackmann, T. J., and J. L. Firkins. 2015. Maximizing efficiency of rumen microbial protein production. Front. Microbiol. 6:465. https:/ /doi.org/10.3389/fmicb.2015.00465.

Higgs, R. 2014. Development of a dynamic rumen and gastro-intestinal model in the Cornell Net Carbohydrate and Protein System to predict the nutrient supply and requirements of dairy cattle. $\mathrm{PhD}$ dissertation, Department of Animal Science, Cornell University, Ithaca, NY.

Higgs, R. J., L. E. Chase, D. A. Ross, and M. E. Van Amburgh. 2015. Updating the Cornell Net Carbohydrate and Protein System feed library and analyzing model sensitivity to feed inputs. J. Dairy Sci. 98:6340-6360. https://doi.org/10.3168/jds.2015-9379.

Higgs, R. J., L. E. Chase, and M. E. Van Amburgh. 2012. Development and evaluation of equations in the Cornell Net Carbohydrate and Protein System to predict nitrogen excretion in lactating dairy cows. J. Dairy Sci. 95:2004-2014. https://doi.org/10.3168/jds.2011 -4810 .

Huhtanen, P., and A. N. Hristov. 2009. A meta-analysis of the effects of dietary protein concentration and degradability on milk protein yield and milk N efficiency in dairy cows. J. Dairy Sci. 92:32223232. https://doi.org/10.3168/jds.2008-1352.

Huhtanen, P., K. Kaustell, and S. Jaakkola. 1994. The use of internal markers to predict total digestibility and duodenal flow of nutrients in cattle given six different diets. Anim. Feed Sci. Technol. 48:211-227. https://doi.org/10.1016/0377-8401(94)90173-2.

Ipharraguerre, I. R., and J. H. Clark. 2005. Impacts of the source and amount of crude protein on the intestinal supply of nitrogen fractions and performance of dairy cows. J. Dairy Sci. 88:E22-E37. https://doi.org/10.3168/jds.S0022-0302(05)73134-9.

Karlsson, J., R. Spörndly, M. Lindberg, and K. Holtenius. 2018. Replacing human-edible feed ingredients with by-products increases net food production efficiency in dairy cows. J. Dairy Sci. 101:7146-7155. https://doi.org/10.3168/jds.2017-14209.

Lean, I. J., T. K. Webster, W. Hoover, W. Chalupa, C. J. Sniffen, E. Evans, E. Block, and A. R. Rabiee. 2005. Effects of BioChlor and Fermenten on microbial protein synthesis in continuous culture fermenters. J. Dairy Sci. 88:2524-2536. https://doi.org/10.3168/ jds.S0022-0302(05)72930-1.

Lemosquet, S., J. Guinard-Flament, G. Raggio, C. Hurtaud, J. Van Milgen, and H. Lapierre. 2010. How does increasing protein supply or glucogenic nutrients modify mammary metabolism in lactating dairy cows? Pages 175-186 in Proc. Energy and Protein Metabolism and Nutrition. EAAP Publication No. 127. G. M. Crovetto, 
ed. Wageningen Academic Publishers, Wageningen, the Netherlands.

Lobley, G. E. 2007. Protein-energy interactions: Horizontal aspects. Pages 445-461 in Energy and Protein Metabolism and Nutrition. I. Ortigues-Marty, ed. EAAP Publication. Wageningen Academic Publishers, Wageningen, the Netherlands.

Mertens, D. R. 2002. Gravimetric determination of amylase-treated neutral detergent fiber in feeds with refluxing in beakers or crucibles: Collaborative study. J. AOAC Int. 85:1217-1240.

Mutsvangwa, T., K. L. Davies, J. J. McKinnon, and D. A. Christensen. 2016. Effects of dietary crude protein and rumen-degradable protein concentrations on urea recycling, nitrogen balance, omasal nutrient flow, and milk production in dairy cows. J. Dairy Sci. 99:6298-6310. https://doi.org/10.3168/jds.2016-10917.

Noblet, J., Y. Henry, and S. Dubois. 1987. Effect of protein and lysine levels in the diet on body gain composition and energy utilization in growing pigs. J. Anim. Sci. 65:717-726. https://doi.org/10 $.2527 /$ jas1987.653717x

Penner, G. B., L. L. Guan, and M. Oba. 2009. Effects of feeding Fermenten on ruminal fermentation in lactating Holstein cows fed two dietary sugar concentrations. J. Dairy Sci. 92:1725-1733. https:// doi.org/10.3168/jds.2008-1706.

Raffrenato, E., D. A. Ross, and M. E. Van Amburgh. 2018. Development of an in vitro method to determine rumen undigested aNDFom for use in feed evaluation. J. Dairy Sci. 101:9888-9900. https: //doi.org/10.3168/jds.2018-15101.

Roche, J. R., N. C. Friggens, J. K. Kay, M. W. Fisher, K. J. Stafford, and D. P. Berry. 2009. Invited review: Body condition score and its association with dairy cow productivity, health, and welfare. J. Dairy Sci. 92:5769-5801. https://doi.org/10.3168/jds.2009-2431.

Russell, J. B., H. J. Strobel, and G. J. Chen. 1988. Enrichment and isolation of a ruminal bacterium with a very high specific activity of ammonia production. Appl. Environ. Microbiol. 54:872-877. https://doi.org/10.1128/AEM.54.4.872-877.1988.

Russomanno, K. L., T. F. Christoph, R. J. Higgs, and M. E. Van Amburgh. 2013. Utilization of byproducts from human food production as feedstuffs for dairy cattle and relationship to greenhouse gas emissions and environmental efficiency. J. Dairy Sci. 96(ESuppl. 1):35

Sakomura, N., J. Fernandes, R. Neme, C. Rabelo, F. Longo, and I. Ortigues-Marty. 2007. Maintenance protein requirement and efficiency of utilization in poultry. Page 547 in Energy and Protein Metabolism and Nutrition. I. Ortigues-Marty, ed. EAAP Publication. Wageningen Academic Publishers, Wageningen, the Netherlands.

Santos, F. A. P., J. E. P. Santos, C. B. Theurer, and J. T. Huber. 1998. Effects of rumen-undegradable protein on dairy cow performance: A 12-year literature review. J. Dairy Sci. 81:3182-3213. https://doi .org/10.3168/jds.S0022-0302(98)75884-9.

St-Pierre, N. R. 2007. Design and analysis of pen studies in the animal sciences. J. Dairy Sci. 90:E87-E99. https://doi.org/10.3168/ jds.2006-612.
Tylutki, T. P., D. G. Fox, V. M. Durbal, L. O. Tedeschi, J. B. Russell, M. E. Van Amburgh, T. R. Overton, L. E. Chase, and A. N. Pell. 2008. Cornell Net Carbohydrate and Protein System: A model for precision feeding of dairy cattle. Anim. Feed Sci. Technol. 143:174202. https://doi.org/10.1016/j.anifeedsci.2007.05.010.

Tyrrell, H. F., and J. T. Reid. 1965. Prediction of the energy value of cow's milk. J. Dairy Sci. 48:1215-1223. https://doi.org/10.3168/ jds.S0022-0302(65)88430-2.

Van Amburgh, M. E., E. A. Collao-Saenz, R. J. Higgs, D. A. Ross, E. B. Recktenwald, E. Raffrenato, L. E. Chase, T. R. Overton, J. K. Mills, and A. Foskolos. 2015. The Cornell Net Carbohydrate and Protein System: Updates to the model and evaluation of version 6.5. J. Dairy Sci. 98:6361-6380. https://doi.org/10.3168/jds.2015 $-9378$.

Van Soest, P. J. 2015. The Detergent System for Analysis of Foods and Feeds. Cornell University, Ithaca, NY.

VandeHaar, M. J., and N. St-Pierre. 2006. Major advances in nutrition: Relevance to the sustainability of the dairy industry. J. Dairy Sci. 89:1280-1291. https://doi.org/10.3168/jds.S0022 -0302(06)72196-8.

Waldo, D. R., L. W. Smith, and E. L. Cox. 1972. Model of cellulose disappearance from the rumen. J. Dairy Sci. 55:125-129. https:// doi.org/10.3168/jds.S0022-0302(72)85442-0.

Wallace, R. J., N. McKain, and C. J. Newbold. 1990. Metabolism of small peptides in rumen fluid. Accumulation of intermediates during hydrolysis of alanine oligomers, and comparison of peptidolytic activities of bacteria and protozoa. J. Sci. Food Agric. 50:191-199. https://doi.org/10.1002/jsfa.2740500207.

Wallace, R. J., C. J. Newbold, B. J. Bequette, J. C. MacRae, and G. E. Lobley. 2001. Increasing the flow of protein from ruminal fermentation. Asian-Australas. J. Anim. Sci. 14:885-893. https://doi .org/10.5713/ajas.2001.885

Waltner, S. S., J. P. McNamara, and J. K. Hillers. 1993. Relationships of body condition score to production variables in high producing Holstein dairy cattle. J. Dairy Sci. 76:3410-3419. https://doi.org/ 10.3168/jds.S0022-0302(93)77679-1.

Wilkinson, J. M., and M. R. F. Lee. 2017. Review: Use of humanedible animal feeds by ruminant livestock. Animal 12:1735-1743. https://doi.org/10.1017/S175173111700218X.

Yang, C. M., and J. B. Russell. 1993. Effect of monensin on the specific activity of ammonia production by ruminal bacteria and disappearance of amino nitrogen from the rumen. Appl. Environ. Microbiol. 59:3250-3254. https://doi.org/10.1128/AEM.59.10.3250 $-3254.1993$.

\section{ORCIDS}

S. W. Fessenden ๑ https://orcid.org/0000-0002-8434-1165

D. A. Ross (ำ https://orcid.org/0000-0002-6692-4674

E. Block 나 https://orcid.org/0000-0003-2588-3236

M. E. Van Amburgh () https://orcid.org/0000-0003-3728-6092 